\title{
HUBUNGAN TINGKAT STRES DENGAN KUALITAS TIDUR PADA MAHASISWA AKHIR S1 KESEHATAN MASYARAKAT UNIVERSITAS PAHLAWAN TUANKU TAMBUSAI
}

\author{
Zurrahmi Z.R $^{1}$, Sri Hardianti ${ }^{2}$, Fitria Meiriza Syahasti ${ }^{3}$ \\ Program Studi Kebidanan \\ Universitas Pahlawan Tuanku Tambusai \\ zurrahmi10@gmail.com¹, ncusri@gmail.com²
}

\begin{abstract}
Sleep is a basic need for everyone. In conditions of rest and sleep, the body performs a recovery process to restore the body's stamina to be in optimal condition. Poor sleep quality is caused by depression, anxiety disorders, a lifestyle that demands work or social activities and one of them is stress. The impact of lack of sleep causes a person to have difficulty concentrating, fatigue, headaches, feeling unwell, lazy, decreased memory, confusion, and has an impact on the ability to make decisions. The purpose of this study was to analyze the relationship between stress levels and sleep quality in undergraduate students of Public Health at Pahlawan Tuanku Tambusai University in 2021. This type of research was a descriptive correlation study with a cross sectional design. This research was conducted in July 2021 with a total sample of 18 undergraduate students of Public Health at Pahlawan Tuanku Tambusai University obtained using a total sampling technique. Data collection techniques using a questionnaire. Analysis of the data used is univariate analysis and bivariate analysis with Chi Square test. The results showed that from 18 respondents, 12 respondents (67\%) experienced moderate stress levels and 13 respondents (70\%) experienced poor sleep quality. The results of statistical tests show that there is a significant relationship between stress levels and sleep quality in final students with $p$ value $=0.003$. By conducting this research, researchers expect students to prevent stress that can affect sleep quality.
\end{abstract}

Keyword $\quad$ : Sleep Quality, Final Student, Stress Level

\begin{abstract}
ABSTRAK
Tidur merupakan kebutuhan dasar setiap orang. Pada kondisi istirahat dan tidur, tubuh melakukan proses pemulihan untuk mengembalikan stamina tubuh hingga berada dalam kondisi yang optimal. Kualitas tidur yang tidak baik disebabkan oleh depresi, gangguan kecemasan, gaya hidup baik tuntutan pekerjaan atau kegiatan sosial dan salah satunya adalah stress. Dampak kurang tidur menyebabkan seseorang sulit untuk berkonsentrasi, keletihan, sakit kepala, merasa tidak enak badan, malas, daya ingat menurun, bingung, serta berdampak pada kemampuan dalam mengambil keputusan. Tujuan penelitian ini adalah untuk menganalisis hubungan tingkat stres dengan kualitas tidur pada mahasiswa akhir S1 Kesehatan Masyarakat Universitas Pahlawan Tuanku Tambusai tahun 2021. Jenis penelitian ini adalah penelitian deskriptif korelasi dengan desain Cross Sectional. Penelitian ini dilakukan pada bulan Juli 2021 dengan jumlah sampel 18 orang mahasiswa akhir S1 Kesehatan Masyarakat Universitas Pahlawan Tuanku Tambusai diperoleh menggunakan teknik total sampling. Teknik pengumpulan data menggunakan kuesioner. Analisa data yang digunakan adalah analisa univariat dan analisa bivariat dengan uji Chi Square. Hasil penelitian didapatkan bahwa dari 18 responden sebanyak 12 responden $(67 \%)$ mengalami tingkat stres sedang dan sebanyak 13 responden (70\%) mengalami kualitas tidur buruk. Dari hasil uji statistik menunjukkan ada hubungan yang signifikan antara tingkat stres dengan kualitas tidur pada mahasiswa akhir dengan $p$ value $=0,003$. Dengan diadakan penelitian ini peneliti mengharapkan kepada mahasiswa untuk mencegah stress yang dapat mempengaruhi kualitas tidur.
\end{abstract}

Kata Kunci : Kualitas Tidur, Mahasiswa Akhir, Tingkat Stres 


\section{PENDAHULUAN}

Tidur merupakan kebutuhan dasar setiap orang. Pada kondisi istirahat dan tidur, tubuh melakukan proses pemulihan untuk mengembalikan stamina tubuh hingga berada dalam kondisi yang optimal (Pranoto, 2010). Tidur yang baik adalah tidur yang berkisar antara 7-8 jam. Kualitas tidur dikatakan baik jika tidak menunjukkan tanda-tanda kekurangan tidur dan tidak mengalami masalah dalam tidur. Namun tidak semua orang mengalami tidur yang baik (Awal, 2017).

Kualitas tidur adalah kebutuhan tidur yang cukup tidak hanya ditentukan oleh faktor jam tidur (kuantitas tidur), tetap juga oleh kedalaman tidur (kualitas tidur). Kualitas tidur meliputi aspek kuantitatif dan kualitatif tidur, seperti lamanya tidur, waktu yang diperlukan untuk bisa tertidur, frekuensi terbangun dan aspek subjektif seperti kedalaman dan kepulasan tidur. Kualitas tidur dikatakan baik jika tidak menunjukkan tanda-tanda kekurangan tidur dan tidak mengalami masalah dalam tidur, kualitas tidur yang buruk merupakan faktor resiko terjadinya masalah fisik dan psikologis. Masalah fisik yang dapat ditimbulkan antara lain kelelahan, nyeri kepala primer, dan penurunan sistem imun (Redline, dkk, 2017).

Faktor yang dapat mempengaruhi kualitas tidur seseorang termasuk juga kelelahan. Kelelahan berbanding terbalik dengan kualitas tidur yang di alami seseorang. Semakin tinggi tingkat kelelahan yang dialami seseorang, maka kualitas tidurnya pun semakin buruk. Kualitas tidur pada usia dewasa awal berkisar 7 sampai 9 jam, namun ternyata sekitar 6 jam sehari karna faktor aktifitas dan kehidupan sosial. Hal ini akan memberikan pengaruh terhadap waktu tidur.

Secara global prevalensi gangguan kualitas tidur di dunia bervariasi mulai 15,3\%-39,2\%. Data Indonesia menunjukkan sebagian besar kualitas tidur pada remaja kurang terpenuhi yaitu sebanyak 63\% (Wahid, Dkk. 2019 ). Di provinsi Riau gangguan kualitas tidur pada mahasiswa sebanyak 84\% (Syafrianda J, dkk, 2015 dalam Kiki \& Sinta, 2019).

Kualitas tidur seseorang dikatakan baik apabila tidak menunjukkan berbagai tanda kekurangan tidur dan tidak mengalami masalah dalam tidurnya, kurang tidur ini menyebabkan banyak efek seperti kehitaman di sekitar mata, bengkak di kelopak mata, konjungtiva kemerahan, dan mata terlihat cekung, kantuk yang berlebihan, tidak mampu berkonsentrasi dan terlihat keletihan, sakit kepala, merasa tidak enak badan, malas, daya ingat menurun, bingung dan kemampuan mengambil keputusan menurun (Hidayat, 2012).

Pada mahasiswa semester akhir kebutuhan tidur akan meningkat menjadi 7,5 sampai 8,5 jam setiap hari namun waktu untuk tidur berubah. Pada mahasiswa semester akhir justru menunda waktu untuk tidur sehingga sebagian besar mereka mengalami jatuh tertidur sampai hari sudah larut dan terbangun di pagi buta. Saat orang lain akan beristirahat dan tidur pada pukul 21:00 atau 22:00 namun pada mahasiswa semester akhir justru dituntut untuk menyelesaikan tugas perkuliahan sehingga siklus tidur bangun menjadi tidak seimbang (Yaqin, 2016).

Kualitas tidur yang tidak baik disebabkan oleh depresi, gangguan kecemasan, gaya hidup baik tuntutan pekerjaan atau kegiatan sosial dan salah satunya adalah stres. Stres merupakan respon tubuh yang sifatnya nonspesifik terhadap setiap tuntutan beban atasnya. Stres yaitu mengacu pada peristiwa yang dirasakan membahayakan kesejahteraan fisik dan psikologis seseorang (Armiyanti, dkk, 2016). Pada saat stress terjadi peningkatan hormon epinefrin, norepinefrin, dan kortisol yang mempengaruhi susunan saraf pusat dan menimbulkan keadaan terjaga dan meningkatkan kewaspadaan sistem saraf pusat. Selain itu, perubahan hormon 
tersebut juga mempengaruhi siklus tidur Non Rapid Eye Movement (NREM) dan Rapid Eye Movement (REM) sehingga dapat membuat seseorang sering terbangun pada malam hari dan mimpi buruk (Sherwood, 2011).

Stres dibagi menjadi beberapa tingkatan diantaranya adalah stres normal, stres ringan, stres sedang, stres berat. Stres normal biasanya dapat dialami secara alamiah oleh stiap individu (Suzane L, 2017). Stres ringan dapat diartikan sebagai stres yang dihadapi selama kurun waktu beberapa menit. Stres sedang adalah dimana fase ini ditandai dengan kewaspadaan, fokus pada indera penglihatan dan pendengaran, peningkatan ketegangan dalam batas toleransi dan mampu mengatasi situasi yang dapat mempengaruhi dirinya (Mardiana \& Zelfini, 2014). Stres berat adalah keadaan dimana terjadi dalam beberapa minggu sampai dengan beberapa tahun (Psychology Foundation of Australia, 2010).

Dampak negatif stres dan kualitas tidur menjadi penghambat mahasiswa tingkat akhir untuk meraih kesuksesan akademik yaitu lulus dengan IPK yang tertinggi. Berdasarkan penelitian yang dilakukan oleh Widodo (2017) hasilnya yaitu, mahasiswa yang beresiko mengalami gangguan tidur 22\% juga beresiko memiliki batas nilai ketuntasan yang rendah atau Grade Point Average < 2.0. Prestasi akademik mahasiswa yang mengalami stres akibat gangguan kualitas tidur juga lebih rendah dari pada mahasiswa yang cukup tidur (Sarjana Widodo, 2017).

Stres yang dialami mahasiswa berdampak secara fisik, emosional, kognitif, maupun interpersonal. Mahasiswa menjadi tidak bersemangat dan sulit berkonsentrasi ketika bimbingan sehingga tidak dapat menyelesaikan tugas akhir tepat waktu. Ada dua faktor penyebab stres pada mahasiswa yang sedang menyusun skripsi yaitu faktor eksternal dan internal. Faktor internal berupa kemampuan maupun kecerdasan mahasiswa itu sendiri. Sedangkan faktor eksternal berupa tuntunan kampus, keluarga, maupun finansial (Broto, 2016).

Berdasarkan hasil survei pendahuluan yang saya lakukan, didapatkan bahwa dari 5 orang mahasiswa akhir S1 Kesehatan Masyarakat di Universitas Pahlawan Tuanku Tambusai terdapat 2 orang yang mengalami stres ringan dan 3 orang yang tidak mengalami stres. Serta 3 orang diantaranya mengalami gangguan kualitas tidur dan 2 orang yang tidak mengalami gangguan kualitas tidur. Berdasarkan hal tersebut penulis merasa perlu melakukan penelitian "Hubungan Tingkat Stres Dengan Kualitas Tidur Pada Mahasiswa Akhir S1 Kesehatan Masyarakat Universitas Pahlawan Tuanku Tambusai tahun 2021". Penelitian ini bertujuan untuk mengetahui hubungan tingkat stres dengan kualitas tidur pada mahasiswa akhir S1 Keperawatan Universitas Pahlawan Tuanku Tambusai tahun 2021.

\section{METODE}

Desain yang digunakan dalam penelitian ini adalah deskriptif korelasi dengan menggunakan pendekatan Cross sectional. Penelitian ini dilakukan pada tanggal 12-14 Juli 2021 di Universitas Pahlawan Tuanku Tambusai.

Populasi dalam penelitian ini yaitu seluruh mahasiswa/i S1 Kesehatan Masyarakat tingkat akhir yang berjumlah 18 Orang di Universitas Pahlawan Tuanku Tambusai. Sampel dalam penelitian ini adalah mahasiswa S1 Kesehatan Masyarakat tingkat akhir yang berjumlah 18 orang di Universitas Pahlawan Tuanku Tambusai. Dalam penelitian ini teknik pengambilan sampel dilakukan dengan menggunakan teknik total sampling. Peneliti menggunakan alat pengumpulan data berupa lembar kuesioner. Pada penilaian tingkat stres menggunakan kuesioner Fitriani \& Ratnaningtyas, (2019). Kuesioner yang digunakan adalah skala likert yang berisi 16 pernyataan. 8 
pernyataan positif dan 8 pernyataan negative. Kuesioner pada kualitas tidur menggunakan kuesioner PSQI (The Pittsburgh Sleep Quality Index).

\section{HASIL}

Tujuan penelitian ini untuk mengetahui hubungan tingkat stres dengan kualitas tidur pada mahasiswa akhir S1 Kesehatan Masyarakat Universitas Pahlawan Tuanku Tambusai. Pengumpulan data diperoleh melalui penyebaran kuesioner yang dilakukan pada bulan Juli tahun 2021 di Universitas Pahlawan Tuanku Tambusai dengan jumlah sampel sebanyak 18 orang. Dari penyebaran kuesioner didapatkan hasil sebagai berikut:

\section{Analisa Univariat}

Analisa univariat adalah analisis yang bertujuan untuk mendiskripsikan berbagai karakteristik data penelitian. Karakteristik responden tersebut dapat dilihat pada tabel dibawah ini :

Tabel 1. Distribusi Frekuensi Tingkat Stres Pada Mahasiswa Akhir S1 Kesehatan Masyarakat Universitas Pahlawan Tuanku Tambusai

\begin{tabular}{cccc}
\hline No & Tingkat Stres & Jumlah & $\begin{array}{c}\text { Persentase } \\
(\boldsymbol{\%})\end{array}$ \\
\hline 1. & Stres ringan & 4 & $22 \%$ \\
2. & Stres sedang & 11 & $61 \%$ \\
3. & Stres berat & 3 & $17 \%$ \\
\hline
\end{tabular}

\begin{tabular}{ccc}
\hline Total & 18 & $\mathbf{1 0 0 \%}$ \\
\hline Keterangan : Hasil Penelitian
\end{tabular}

Seperti yang disajikan pada tabel 1 dapat dilihat dari 18 responden terdapat 4 responden $(22 \%)$ mengalami tingkat stres ringan, 12 responden $(67 \%)$ mengalami tingkat stres sedang, dan 2 responden (11\%) mengalami tingkat stres berat.

Tabel 2. Distribusi Frekuensi Kualitas Tidur Pada Mahasiswa S1 Kesehatan Masyarakat Tingkat Akhir Universitas Pahlawan Tuanku Tambusai

\begin{tabular}{|c|c|c|c|}
\hline No & Kualitas Tidur & Jumlah & $\begin{array}{c}\text { Persentase } \\
(\%)\end{array}$ \\
\hline 1. & Buruk & 13 & $70 \%$ \\
\hline \multirow[t]{2}{*}{2.} & Baik & 5 & $30 \%$ \\
\hline & Total & 18 & $100 \%$ \\
\hline
\end{tabular}

Seperti yang disajikan pada tabel 2 dapat dilihat dari 18 responden terdapat 13 responden $(70 \%)$ mengalami kualitas tidur buruk, dan 5 responden (30\%) mengalami kualitas tidur baik.

\section{Analisa Bivariat}

Analisa bivariat ini digunakan untuk mengetahui hubungan tingkat stres dengan kualitas tidur pada mahasiswa S1 Kesehatan Masyarakat Universitas pahlawan Tuanku Tambusai tahun 2021, dengan menggunakan uji statistik ChiSquare $\left(\mathrm{X}^{2}\right)$, dengan derajat kepercayaan $\alpha$ $<0,05$.

Tabel 3. Hubungan Tingkat Stres Dengan Kualitas Tidur Pada Mahasiswa S1 Kesehatan Masyarakat Tingkat Akhir Universitas Pahlawan Tuanku Tambusai

\begin{tabular}{|c|c|c|c|c|c|c|c|}
\hline \multirow{3}{*}{$\begin{array}{c}\text { Tingkat } \\
\text { Stres }\end{array}$} & \multicolumn{7}{|c|}{ Kualitas Tidur } \\
\hline & \multicolumn{2}{|c|}{ Buruk } & \multicolumn{2}{|c|}{ Baik } & \multicolumn{2}{|c|}{ Total } & \multirow[t]{2}{*}{ P Value } \\
\hline & $\mathbf{F}$ & $\%$ & $\mathbf{F}$ & $\%$ & $\mathbf{F}$ & $\%$ & \\
\hline Stres Ringan & 1 & $25 \%$ & 3 & $75 \%$ & 4 & $100 \%$ & 0,003 \\
\hline Stres Sedang & 8 & $73 \%$ & 3 & $27 \%$ & 11 & $100 \%$ & \\
\hline Stres Berat & 2 & $75 \%$ & 1 & $25 \%$ & 3 & $100 \%$ & \\
\hline Total & 13 & $70 \%$ & 5 & $30 \%$ & 18 & $100 \%$ & \\
\hline
\end{tabular}

Berdasarkan tabel 3 dapat dilihat bahwa dari 4 responden dengan tingkat stres ringan terdapat 3 responden $(75 \%)$ memiliki kualitas tidur baik. Dari 11 responden dengan tingkat stres sedang terdapat 3 responden $(27 \%)$ memiliki 
kualitas tidur baik. Sedangkan dari 3 responden dengan tingkat stres berat terdapat 1 responden $(25 \%)$ memiliki kualitas tidur baik.

Berdasarkan hasil uji statistik diperoleh nilai $p$ value $=0,003 \leq 0,05$ yang artinya ada hubungan antara tingkat stres dengan kualitas tidur pada mahasiswa akhir S1 Kesehatan Masyarakat Universitas Pahlawan Tuanku Tambusai.

\section{PEMBAHASAN}

Berdasarkan hasil penelitian dengan judul "Hubungan Tingkat Stres Dengan Kualitas Tidur Pada Mahasiswa Akhir S1 Kesehatan Masyarakat Universitas Pahlawan Tuanku Tambusai Tahun 2021", maka dapat diuraikan pembahasan sebagai berikut :

Hasil Analisa bivariat dari variabel hubungan tingkat stres dengan kualitas tidur pada mahasiswa akhir S1 Kesehatan Masyarakat Universitas Pahlawan Tuanku Tambusai Tahun 2021 diperoleh nilai $p$ value $=0,003$ ( $p$ value $\leq 0,05)$ dimana, dari 3 responden yang memiliki stres berat, terdapat 2 responden $(75 \%)$ yang mengalami kualitas tidur buruk. Menurut asumsi peneliti bahwa hal ini terjadi karena stres yang terlalu berat akan berdampak pada peningkatan ketegangan dan kesulitan dalam memulai waktu tidur.

Menurut teori Lukaningsih dan Bandiyah (2011) stres merupakan respon tubuh yang bersifat tidak spesifik terhadap setiap tuntutan atau beban kerja. Seseorang yang memiliki stres akan timbul gejalagejala seperti sakit kepala, mudah marah, penurunan berat badan, gelisah atau kecemasan yang berlebihan, sulit tidur, serta sulit untuk berkonsentrasi.

Menurut teori Sherwood (2011), pada saat stres terjadi peningkatan hormon epinefrin, noreprinefrin, dan kortisol yang mempengaruhi susunan saraf pusat sehingga menimbulkan keadaan terjaga dan meningkatkan kewaspadaan pada sistem saraf pusat. Hal ini akan mempengaruhi kualitas tidur pada individu.
Penelitian ini sesuai dengan penelitian yang dilakukan oleh Fitriani \& Ratnaningtyas mengenai Hubungan Stres Dengan Kualitas Tidur Pada Mahasiswa Tingkat Akhir di STIKes Kharisma Persada. Hasil penelitian menunjukkan ada hubungan antara tingkat stres dengan kualitas tidur.

Dari 3 responden dengan tingkat stres berat, terdapat 1 responden $(25 \%)$ memiliki kualitas tidur baik. Menurut asumsi peneliti hal ini terjadi karena faktor lingkungan yang mendukung seperti lingkungan yang nyaman dan tenang.

Menurut Rahmadini, (2016) faktor lingkungan yang nyaman dan tenang dapat mempengaruhi kualitas tidur seseorang. Lingkungan dapat meningkatkan atau dapat menghalangi seseorang untuk tidur. Pada lingkungan yang tenang memungkinkan seseorang untuk tidur dengan nyenyak. Sebaliknya lingkungan yang ribut, bising, gaduh, kotor, terang, dan panas akan dapat menghambat seseorang untuk tidur.

Sedangkan dari 4 responden stres ringan, terdapat 1 responden (25\%) memiliki kualitas tidur buruk. Menurut asumsi peneliti hal ini disebabkan oleh aktivitas yang membuat kelelahan fisik. Kelelahan fisik sepanjang hari dapat menyebabkan kualitas tidur terganggu.

Menurut Potter \& Perry, (2015) individu dengan kelelahan sepanjang hari akan merasakan ketidaknyamanan pada tubuh saat malam hari. Hal ini akan menyebabkan individu sulit rileks sehingga sulit untuk memulai tidurnya. Namun, tingkat rileks setiap individu berbeda-beda, sehingga walaupun ada beberapa responden yang tidak mengalami kelelahan akibat aktivitas responden tetap dapat merasakan kesulitan untuk rileks karena hanya melakukan hal yang sama sepanjang hari.

\section{KESIMPULAN}

Sebagian besar responden mahasiswa akhir S1 Kesehatan Masyarakat Universitas Pahlawan Tuanku Tambusai mengalami stres sedang. Sebagian besar responden 
mahasiswa akhir S1 Kesehatan Masyarakat Universitas Pahlawan Tuanku Tambusai mengalami kualitas tidur. Ada hubungan antara tingkat stres dengan kualitas tidur pada mahasiswa akhir S1 Kesehatan Masyarakat Universitas Pahlawan Tuanku Tambusai tahun 2021.

\section{UCAPAN TERIMAKASIH}

Dalam penelitian ini, peneliti banyak mendapatkan bantuan dari berbagai pihak. Sehubungan dengan hal tersebut peneliti mengucapkan terima kasih kepada responden, LPPM Universitas Pahlawan Tuanku Tambusai, serta pihak-pihak yang telah banyak membantu dan berkontribusi dalam terselesaikannya penelitian ini.

\section{DAFTAR PUSTAKA}

Armyanti ita, dkk. (2016). Faktor Yang Mempengaruhi Tingkat Stres Pada Tenaga Kesehatan Di RS Universitas Tanjung Pura Pontianak Tahun 2015. Jurnal Cerebellum. Volume 2 Nomor 3.

Carolin, (2010). Abnormal psychology in a changing. Ed 7. Jakarta : Salemba Medica.

Damayanti, dkk. (2014). Faktor-Faktor Yang Berhubungan Dengan Gangguan Pemenuhan Kebutuha Tidur Pasien Yang Dirawat Di Ruang Baji Kamase RSUD Labuang Baji Makassar.

Donsu. (2016). Metodologi Penelitian Keperawatan. Yogyakarta. PUSTAKABARUPRESS.

Hasono. (2010). Statistik Kesehatan. Jakarta. Rajawali Pres.

Jutomo lewi, dkk (2019). Stres, Pola Konsumsi, Dan Pola Istirahat Mahasiswa Tingkat Ahir Fakultas Kesehatan Masyarakat Universitas Nusa Cendana. Journal of public health. Volume 1 Nomor 2.
Khairoh \& rosyaria. (2019). Effleurage Massage Aromatherapy Lavender Sebagai Terapi Kualitas Tidur Malam. Surabaya. Cv Jakad Publishing.

Kiki \& Sinta (2019). Hubungan Kualitas Tidur Dengan Indeks Prestasi Kumulatif Mahasiswa Akademi Kebidanan Anugerah Bintan. Jurnal Cakrawala Kesehatan. Vol X Nomor 02.

Morgan Nicola. (2014). Panduan Mengatasi Stres Bagi Remaja. Tangerang Selatan. Gemilang.

Notoatmodjo. (2012). Metodologi Penelitian Kesehatan. Jakarta. PT RINEKA CIPTA.

Nursalam. (2013). Metodologi Penelitian Ilmu Keperawatan. Jakarta. Salemba Medika

Petter \& perry (2015). Buku Ajar Funfamental Keperawatan, Jakarta. Graha Pustaka.

Putri, V,A. (2018). Pengaruh Kualitas Tidur Terhadap Kejadian Hipertensi DI Rumah Sakit Umum Daerah Dr. H. Abdul Molek Bandar Lampung. SKRIPSI. Lampung, Fakultas Kedokteran.

Rafknowledge. (2017). Insomnia Dan Gangguan Tidur Lainnya. Jakarta. Pt Elex Media Komputindo.

Rahmadini, D. (2016). Penagruh Penggunaan Lampu Pada Saat Tidur Terhadap Kualitas Tidur Pada Mahasiswa Fakultas Kedokteran Universitas Muhammadiyah Palembang.

Rosyad sabila yafi. (2018). Tingkat Stres Sekolah Tinggi Ilmu Kesehatan Yogyakarta Dalam Menyusun Skripsi TA 2018/2019. Cahaya Pendidikan Vol 5 No 1

Safrani, I. (2017). Pengaruh Senam Yoga Terhadap Kualitas Tidur. SKRIPSI. Jawa Timur, Sekolah Tinggi Ilmu Kesehatan Insan Cendekia Medika Jombang.

Sarjana widodo, dkk (2018). Hubungan Antara Tingkat Stress Dengan 
Tingkat Insomnia Pada

Mahasiswa/I Angkatan 2012-2013

Program Studi Pendidikan Dokter

Fakultas Kedokteran Universitas Di

Ponegoro. Jurnal Kedokteran. Vol 6

Nomor 2.

Sutanto \& Fitriana. (2017). Kebutuhan

Dasar Manusia. Yogyakarta :

Pustaka Baru Press.

Vancopa rino. (2012). Beban Kerja Dan

Stres Kerja. Jawa Timur. Qiara Media.

Wahid dkk. (2019) Perilaku Penggunaan Gadget Dengan Kualitas Tidur Pada Remaja. Jurnal kesehatan. Volume 13 nomor 3.

Zafira Hana dkk. (2019). Hubungan Antara

Kualitas Tidur Terhadap Hasil Belajar Mahasiswa Program Studi Pendidikan Dokter Fakultas Kedokteran Universitas Lampung. Artikel Penelitian. Volume 6 Nomor 1. 